\title{
PENGGUNAAN PUPUK BIO MIKORIZA PADA TANAMAN BAWANG MERAH (Allium ascalonium L) SEBAGAI SALAH SATU PENERAPAN PERTANIAN BERKELANJUTAN
}

\author{
Oleh \\ Fikri Fatkhurrahman'), Siswoyo ${ }^{2)}$ \& Azhar $^{3)}$ \\ 1,2,3Politeknik Pembangunan Pertanian Bogor; Jl. Arya Suryalaga (d/h Cibalagung) No.1 \\ Kecamatan Bogor Barat Kota Bogor, Telepon :08518312386, fax:02518312386 \\ Jurusan Pertanian, Polbangtan Bogor, Kota Bogor \\ Email: ${ }^{1}$ apaanitu15@gmail.com, ${ }^{2}$ siswoyo1961@gmail.com \& ${ }^{3}$ azhar.feb1960@gmail.com
}

\begin{abstract}
Abstrak
Pertanian berkelanjutan merupakan salah satu konsep yang tercipta dari buah pikiran manusia bahwa lingkungan tempat manusia berada harus tetap dilestarikan, seiring berkembangnya industrialisasi beserta dampak yang ditimbulkan. Konsep ini menjunjung pada optimalisasi pemanfaatan sumber daya alam diimbangi dengan pemulihan alam itu sendiri, atau pelaksanaan pertanian dengan memperhatikan kapasitas dari alam itu sendiri. Praktek budidaya secara konvensional oleh para petani dengan penggunaan bahan - bahan kimia sintetik yang terus meningkat menyebabkan terjadinya endapan pada media tanam, sehingga perlunya input bahan untuk mengoptimalkan kembali fungsi tanah. Mikoriza merupakan sebuah jamur obligat yang memiliki fungsi untuk perakaran pada tanaman, dilain sisi jamur ini mampu menguraikan unsur unsur dalam tanah sehingga menjadi cadangan nutrisi baik tanaman atau mikroorganisme lain dalam tanah. Tujuan penelitian ini adalah untuk mengubah perilaku petani baik pengetahuan, sikap ataupun keterampilan tentang pentingnya pertanian berkelanjutan jika ditinjau dari segi agro production atau budidaya tanaman dengan pemanfaatan pupuk mikoriza. Penelitian ini berlokasi di Desa Pabedilan Wetan, Kecamatan Pabedilan, Kabupaten Cirebon dengan sampel yaitu petani bawang merah yang tergabung dalam kelompok tani baik ketua, pengurus atau anggota aktif/pasif dengan jumlah total 32 petani. penelitian ini termasuk dalam jenis penelitian deskriptif dengan penyebaran kuesioner melalui wawancara dan diskusi dalam penyuluhan. Berdasarkan hasil perbandingan pre test dan post test yang didapat, menunjukkan bahwa terdapat perubahan perilaku melalui penyuluhan pertanian. Aspek pengetahuan meningkat sebesar 28,7\%, sikap meningkat sebesar 30,6\% dan keterampilan sebesar 43,4\%. Berdasarkan hasil tersebut maka dapat disimpulkan bahwa para petani bawang mampu untuk menerapkan pertanian berkelanjutan dalam aspek budidaya tanaman, dengan catatan bimbingan dan monitoring oleh stakeholder pertanian.
\end{abstract}

Kata Kunci: Pertanian Berkelanjutan, Pupuk Mikoriza \& Perilaku

\section{PENDAHULUAN}

Pertanian adalah kegiatan pemanfaatan sumber daya hayati yang dilakukan manusia untuk menghasilkan bahan pangan, bahan baku industri, atau sumber energi, serta untuk mengelola lingkungan hidupnya. Kegiatan pemanfaatan sumber daya hayati yang termasuk dalam pertanian biasa dipahami orang sebagai budidaya tanaman atau bercocok tanam (crop cultivation) serta pembesaran hewan ternak (raising), meskipun cakupannya dapat pula berupa pemanfaatan mikroorganisme dan bio enzim dalam pengolahan produk lanjutan, seperti pembuatan keju dan tempe, atau sekadar ekstraksi semata, seperti penangkapan ikan atau eksploitasi hutan. (Wikipedia, 2020).

Rukmana (1994), menjelaskan bahwa bawang merah termasuk salah satu komoditas sayuran nasional yang telah lama diusahakan petani secara intensif. Produksi bawang merah sampai saat ini memang belum optimal dan masih tercermin dalam kegaraman cara 
budidaya yang bercirikan spesifik agroekosistem tempat budidaya bawang merah diusahakan. Praktek budidaya secara konvensional oleh para petani dengan penggunaan bahan-bahan kimia yang terus meningkat sehingga terjadilah endapan pada media tanam (tanah) yang petani usahakan. mikoriza berpotensi besar sebagai pupuk hayati karena merupakan salah satu mikroorganisme yang memiliki peranan yang sangat penting bagi tanaman yaitu dapat memfasilitasi penyerapan hara dalam tanah sehingga dapat meningkatkan pertumbuhan tanaman, sebagai penghalang biologis terhadap infeksi patogen akar, meningkatkan ketersediaan air bagi tanaman dan meningkatkan hormon pemacu tumbuh (Prihastuti, 2007).

Menurut Rudy \& Iwan (2011) mengemukakan bahwa, pembangunan berkelanjutan bukan hanya bertumpu pada aspek lingkungan hidup semata, tetapi juga pada pembangunan ekonomi dan sosial, yang satu sama lain saling berkaitan. Dalam kaitan itu, maka implementasi pembangunan pertanian berkelanjutan bukan hanya tugas dari Kementerian Pertanian atau Kementerian Lingkungan Hidup saja namun juga terkait dengan institusi yang luas. Dengan demikian para petani konvensional dapat merubah perilakunya guna untuk meningkatkan skala usaha tani dan mampu mengembangkan segala informasi yang diterima. hasil dari perubahan perilaku petani ini adalah dapat diterapkannya konsep pertanian secara berkelanjutan yang di mana berguna untuk pertanian dimasa yang akan datang.

Pemaparan beberapa permasalahan diatas khususnya dalam permasalahan diseminasi teknologi, perilaku petani dan pertanian berkelanjutan, perlu adanya kajian lebih lanjut sehingga muncul beberapa solusi dan gambaran lebih akan potensi dan pengembangan dari komoditas bawang merah khususnya di Desa Pabedilan Wetan, Kabupaten Cirebon. Berdasarkan permasalahan yang telah diuraikan pada latar belakang maka didapatkannya beberapa rumusan masalah yaitu:

1. Bagaimanakah penerapan teknologi pupuk bio mikoriza pada tanaman bawang merah?

2. Bagaimanakah kondisi perilaku petani bawang merah terhadap pertanian berkelanjutan dan pupuk bio mikoriza?

3. Bagaimanakah perubahan perilaku petani melalui penyuluhan pertanian?

\section{METODE PENELITIAN}

Waktu pelaksanaan kegiatan penelitian tugas akhir dilaksanakan selama tiga bulan, di mana terhitung dari hari Rabu 1 April 2020 sampai dengan Selasa 30 Juni 2020. Selanjutnya adalah tempat pelaksanaan kegiatan penelitian yaitu Kecamatan Pabedilan Kabupaten Cirebon. Desa yang akan dijadikan sebagai desa sampel adalah Desa Pabedilan Wetan. Pengambilan sampel menggunakan teknik quota sampling, dengan kriteria yang diharapkan dapat mewakili karakteristik populasi, kriteria yang akan dijadikan sebagai sampel merupakan ketua kelompok tani, pengurus kelompok tani, anggota kelompok tani aktif/pasif. Sehingga didapatkan jumlah responden sebanyak 32 orang dengan jumlah pada masing - masing kriteria yaitu 4 ketua kelompok tani, 8 pengurus kelompok tani dan 20 anggota aktif /pasif kelompok tani. Instrumen dalam, penelitian ini menggunakan skala rating scale untuk pengetahuan dan keterampilan, sedangkan sikap menggunakan skala likert. Variabel yang diamati adalah perilaku petani yaitu pengetahuan, sikap dan keterampilan terhadap pupuk bio mikoriza dan pertanian berkelanjutan.

Uji validitas dilakukan dengan cara membandingkan nilai t hitung dengan t tabel. Dari keseluruhan item berjumlah 27 item yang diuji, terdapat 5 item yang tidak valid sehingga item dihilangkan atau tidak gunakan. . Nilai alpha cronbach yang digunakan untuk mengukur reliabilitas adalah 0.60 sesuai dengan apa yang dikatan Sugiyono (2016) dalam bukunya, hasil reliabilitas menunjukkan seluruh item memiliki nilai yang lebih besar 
dibandingkan dengan nilai alpha cronbach, artinya bahwa alat ukur/kuesioner yang dimiliki oleh peneliti untuk mengukur pertanian berkelanjutan dan pupuk mikoriza pada petani di Desa Pabedilan Wetan memiliki tingkat ketepatan dan kehandalan yang baik untuk sebuah alat ukur.

Teknik pengumpulan data menggunakan metode: a. Observasi, yaitu kegiatan pengumpulan data dengan melakukan pengamatan secara langsung terhadap objek pengkajian. b. Penyebaran dan pengisian kuesioner, c. Wawancara, yaitu teknik pengumpulan data dengan cara tanya jawab secara langsung dengan petani yang menjadi sampel dalam kajian. d. Studi literatur, pencarian data berdasarkan jurnal/ laporan ilmiah. Dalam mengkaji perilaku petani terhadap penerapan pertanian berkelanjutan pada budidaya bawang merah dianalisis dengan statistik deskriptif sedangkan untuk mengkaji pengujian teknologi pupuk bio mikoriza pada tanaman bawang merah menggunakan independent $t$ test pada software SPSS (Statistical Package for the Social Sciences).

\section{Uji Teknologi}

Uji teknologi ini dilakukan pada tanggal 15 Mei 2020 sampai dengan 25 Juni 2020. Tempat uji teknologi dilakukan pada lahan pekarangan milik peneliti. Alat yang digunakan cangkul, sprayer, ember, tugal, alat tulis, tanda sampel, penggaris. Dan bahan yang digunakan pupuk mikoriza, pestisida nabati, pestisida sintetik, pupuk kandang, bibit bawang merah, bambu. Variabel dependen pengujian ini adalah a) Tinggi tanaman dalam (cm); b) Panjang akar dalam $(\mathrm{cm})$; c) Jumlah umbi.

1. Ho: terdapat pengaruh signifikan panjang daun dengan pemberian mikoriza.

$\mathrm{H} 1$ : terdapat pengaruh tidak signifikan panjang daun dengan pemberian mikoriza.

2. Ho: terdapat pengaruh signifikan panjang akar dengan pemberian mikoriza.

$\mathrm{H} 1$ : terdapat pengaruh tidak signifikan panjang akar dengan pemberian mikoriza.

3. Ho: terdapat pengaruh signifikan jumlah umbi dengan pemberian mikoriza.
H1: terdapat pengaruh tidak signifikan jumlah umbi dengan pemberian mikoriza.

\section{HASIL DAN PEMBAHASAN Gambaran Wilayah}

Desa Pabedilan Wetan merupakan salah satu dari 12 Desa di Wilayah Kecamatan Pabedilan kabupaten Cirebon yang terletak 4 $\mathrm{Km}$ ke arah Barat dari Kecamatan Pabedilan. Desa Pabedilan Wetan berada di ketinggian 26 meter diatas permukaan laut dengan luas wilayah \pm 137.597 Hektar. Suhu rata - rata di wilayah desa Pabedilan Wetan adalah $28^{\circ} \mathrm{C}$ dengan iklim kemarau dan penghujan. jika diklasifikasikan menurut Schmidt-Ferguson maka Desa Pabedilan Wetan termasuk dalam ketegori D yaitu daerah sedang atau hutan musim, menurut data 10 tahun terakhir, bulan kering Desa Pabedilan Wetan berjumlah 5 (Juni - Oktober) sedangkan bulan basah berjumlah 7 (November - Mei).

Pabedilan Wetan merupakan salah satu desa sentra tanaman bawang merah yang dibudidayakan oleh petani setempat. Luasan lahan dengan diiringi irigasi teknis \pm 113 ha. Desa Pabedilan Wetan memiliki empat kelompok tani yaitu: Mrengkel I beranggota 56 petani dengan kelas kelompok lanjut, Mrengkel II beranggota 81 petani dengan kelas kelompok lanjut, Randu beranggota 82 petani dengan kelas kelompok madya, Rungkun Gede beranggota 26 petani dengan kelas kelompok lanjut, selain itu terdapat 2 kelompok wanita tani yaitu Kasturi beranggota 10 orang dan Kartika beranggota 15 orang dengan kelas kelompok lanjut.

\section{Karakteristik Responden}

Petani responden sebagian besar adalah lansia sebanyak $62 \%$ atau 20 petani, untuk usia manula (6 petani atau 19\%) dan dewasa (6 petani atau 19\%). Tingkat pendidikan petani responden mengerucut pada pendidikan formal yang diikuti petani, dengan mayoritas pendidikan sebanyak 56\% yaitu sekolah dasar dan lainnya adalah sekolah menengah pertama $19 \%$, sekolah menengah atas $19 \%$. 


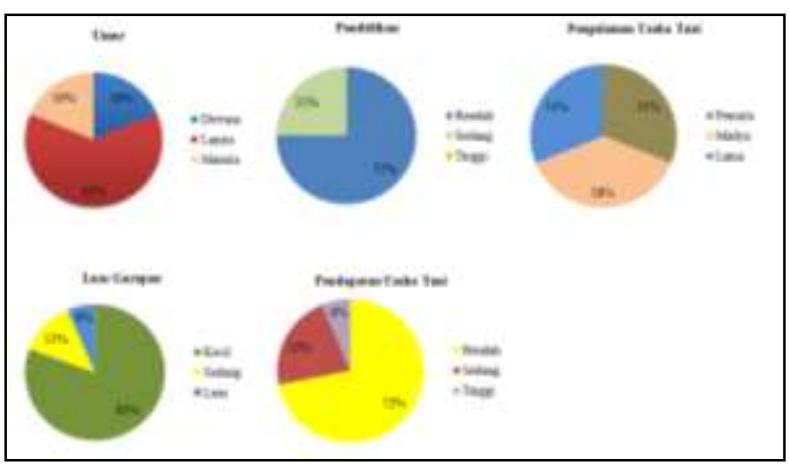

Pengalaman usahatani pada seberapa lama petani menjalankan usahatani tersebut. Pada kriteria pemula rentang yang diberikan yaitu 9 - 16 tahun dengan jumlah petani sebanyak $31 \%$ atau 10 orang, kriteria madya berkisar antara 17 - 25 tahun dengan jumlah petani sebanyak $38 \%$ atau 12 orang, sedangkan para kriteria lama lebih dari 25 tahun dengan jumlah petani sebanyak $31 \%$ atau 10 orang. Klasifikasi luasan garapan didapatkan 3 kriteria, luasan kecil yaitu $0,25-0,83 \mathrm{Ha}$ sebanyak $81 \%$ atau 25 petani, kriteria luasan sedang yaitu $0,83-1,4$ Ha sebanyak $13 \%$ atau 4 petani, kriteria luasan luas yaitu lebih dari 1,4 - 2 Ha sebanyak $6 \%$ atau 2 petani.

Dari 32 responden didapatkan bahwa kriteria petani berpendapatan rendah yaitu antara Rp. 75.000.000 hingga Rp. 175.000.000 terdapat $72 \%$ atau 23 petani, kriteria petani ber pendapatan sedang yaitu berkisar antara $\mathrm{Rp}$. 176.000.000 - Rp. 351.000 .000 terdapat $22 \%$ atau 7 petani dan kriteria ber pendapatan tinggi yaitu lebih dari Rp. 300.000 .000 sebesar 6\% atau 2 petani.

\section{Uji Teknologi Pupuk Mikoriza Arbuskuler Terhadap Tanaman Bawang Merah}

Perlakuan yang diberikan pada penelitian kali ini adalah penggunaan pupuk mikoriza dan tidak menggunakan pupuk mikoriza, Panjang daun dilakukan dengan pengukuran menggunakan penggaris dari pangkal bawang merah hingga ujung daun tumbuh, pengamatan dilakukan pada usia $2 \mathrm{hst}$ dan terhitung hingga usia pertumbuhan generatif bawang merah yaitu 30hst sehingga menghasilkan 8 pengamatan.

Variabel panjang akar dan banyak umbi dilakukan pada saat pemanenan. Variabel lainnya seperti penggunaan pupuk organik, kondisi iklim, kondisi tanah, hama dan penyakit dianggap sebagai variabel tak diperhitungkan/diteliti. Pelaksanaan analisis

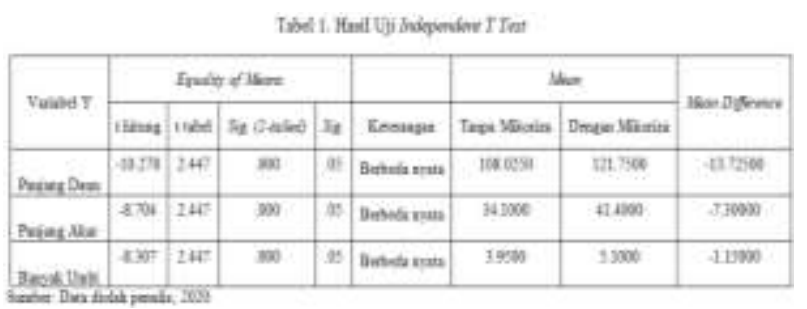

data diawali dengan uji normalitas agar diketahui data bersifat normal yang artinya data berdistribusi secara normal, hasil normalitas menunjukkan data berdistribusi secara normal dan dapat dilakukan uji selanjutnya yaitu independent $t$ test. Data pada tabel 1 menunjukkan perbedaan pupuk mikoriza dan tanpa penggunaan pupuk mikoriza. Pengujian menggunakan uji independent $t$ test sehingga memunculkan nilai perbandingan variabel independen terhadap variabel dependen. $T$ tabel diperoleh dengan (a/2); $\mathrm{df} /(0.05 / 2) ; 6$ sehingga mendapatkan hasil 2.447 pada distribusi nilai t tabel. Variabel panjang daun terlihat nilai sig. 0.000 yang artinya lebih kecil dari 0.05 sebagai standar kesalahan pada penelitian kali ini sedangkan pada $t$ hitung lebih besar dibandingkan $t$ tabel, menunjukkan bahwa rata - rata hasil panjang daun memiliki perbedaan secara nyata antara penggunaan mikoriza dan tanpa

mikoriza. Hal ini dibuktikan dengan nilai mean tanpa mikoriza dan dengan mikoriza yang muncul.

Terlihat bahwa tanaman yang menggunakan mikoriza mampu menampilkan hasil lebih tinggi dengan selisih rata - rata mencapai 13.7 dibandingkan dengan tanpa mikoriza. Artinya bahwa penggunaan mikoriza pada tanaman dapat meningkatkan panjang daun lebih baik bila dibandingkan tanpa menggunakan mikoriza. Hal yang serupa ditunjukkan pada variabel panjang akar dan jumlah umbi, terlihat pada tabel sig. panjang akar dan jumlah umbi bernilai kurang dari 0.000 sebagai standar eror. Dan pada tabel 
mean perlakukan dengan mikoriza mampu menampilkan hasil yang lebih baik dibandingkan dengan tanpa menggunakan mikoriza. Hasil menunjukkan nilai signifikan yang lebih kecil dari taraf error maka Ho dapat diterima pada variabel panjang daun, panjang akar dan jumlah umbi, yang artinnya penggunaan mikoriza pada tanaman bawang merah berbeda secara nyata dibandingkan tanpa mikoriza.

\section{Panjang Daun}

Tabel 2. Hasil Pengamatan Panjang Daun

\begin{tabular}{|l|c|c|c|c|c|c|c|c|}
\hline Ket & 2hst & 6 hst & 10 hst & 14 hst & 18 hst & 22hst & 26hst & 30hst \\
\hline U1 & 0.2 & 3.8 & 8 & 12.8 & 16 & 18.6 & 22.2 & 27.6 \\
\hline U2 & 0 & 3.2 & 7.6 & 12.2 & 15.75 & 18.6 & 21.8 & 27 \\
\hline U3 & 0.4 & 3.2 & 8.2 & 11.6 & 16.5 & 19 & 23 & 27.8 \\
\hline U4 & 0.2 & 3 & 7.6 & 11.6 & 15.75 & 19.6 & 22 & 27.2 \\
\hline Jumlah & 0.8 & 13.2 & 23.8 & 48.2 & 64 & 75.8 & 89 & 109.6 \\
\hline Rata - rata & 0.2 & 3.3 & 7.9 & 12.1 & 16.0 & 19.0 & 22.3 & 27.4 \\
\hline P1 & 0 & 4 & 9 & 14.2 & 17.5 & 20.6 & 24.6 & 29 \\
\hline P2 & 0.4 & 4 & 9.8 & 14 & 18.25 & 21.2 & 24.8 & 30.2 \\
\hline P3 & 0.2 & 4.4 & 9.4 & 13 & 18.5 & 21.6 & 25 & 29.6 \\
\hline U4 & 0.4 & 3.8 & 9 & 14.2 & 19 & 21.8 & 25.2 & 30.3 \\
\hline Jumlah & 1.0 & 16.2 & 37.2 & 55.4 & 73.3 & 85.2 & 99.6 & 119.1 \\
\hline Rata - rata & 0.3 & 4.1 & 9.3 & 13.9 & 18.3 & 21.3 & 24.9 & 29.8 \\
\hline Selisin & 0.1 & 0.8 & 1.4 & 1.8 & 2.3 & 2.4 & 2.7 & 2.4 \\
\hline
\end{tabular}

Sumber: Data diolah penulis, 2020

Ket. U: tanpa mikoriza, P: dengan mikoriza, hst: hari setelah tanam.

Terlihat pada 6 hst mulai terlihat perbedaan dengan ketinggian rerata tanpa mikoriza berkisar $3.3 \mathrm{~cm}$ sedangkan dengan perlakukan mikoriza berkisar $4.1 \mathrm{~cm}$. Pada 10 \& 14 hst perbandingan rerata antara menggunakan mikoriza dan tidak menggunakan semakin membesar, terlihat pada perbandingan rerata hasil. Menurut Suryani dkk (2017) dalam jurnalnya menyebutkan bahwa pemberian mikoriza terhadap tinggi tanaman bawang memiliki pengaruh secara nyata.

Begitu pula apa yang dijelaskan oleh Aprianti dan Suryanto (2018) pada jurnalnya bahwa, terdapat pengaruh nyata penggunaan mikoriza dan PGPR terhadap parameter panjang tanaman. Media tanam yang diberi bahan organik memiliki panjang tanaman yang sama dengan media tanam yang diberi mikoriza, PGPR, bahan organik + mikoriza, bahan oganik + PGPR. Perlakuan yang menghasilkan panjang tanaman paling tinggi yaitu media tanah + bahan organik + mikoriza.

\section{Panjang Akar}

Tabel 3. Hasil Pengamatan Panjang Akar

\begin{tabular}{|l|r|l|r|}
\hline \multicolumn{4}{|c|}{ Panjang Akar } \\
\hline Perlakuan & Hasil & \multicolumn{1}{c|}{ Perlakuan } & \multicolumn{1}{c|}{ Hasil } \\
\hline U1 & 34.6 & P1 & 40 \\
\hline U2 & 34.8 & P2 & 40.6 \\
\hline U3 & 32.8 & P3 & 41.8 \\
\hline U4 & 34.2 & P4 & 43.2 \\
\hline Jumlah & 136.4 & Jumlah & 165.6 \\
\hline Rata-rata & 34.1 & Rata-rata & 41.4 \\
\hline \multicolumn{4}{|c|}{ Selisih rata - rata } \\
\hline
\end{tabular}

Sumber: Data diolah penulis, 2020

Ket. U: tanpa mikoriza, P: dengan mikoriza, hst: hari setelah tanam.

Pemberian mikoriza berpengaruh terhadap panjang akar tanaman bawang merah. Terlihat pada selisih rerata yang menunjukkan bahwa perlakuan dengan menggunakan pupuk mikoriza mampu menghasilkan panjang akar lebih baik dengan selisih sebesar $7.3 \mathrm{~cm}$. Menurut Tinker (1975) mengatakan bahwa, Kolonisasi mikoriza mengubah morfologi akar sedemikian rupa, misalnya dengan menginduksi hipertrofi akar, sehingga mengakibatkan pembesaran sistem akar, dengan demikian luas permukaan akar untuk mengabsorpsi $\mathrm{P}$ menjadi lebih besar.

Fungsi unsur fosfor Menurut Malherbe (1964) mengatakan bahwa, fungsi P terpenting dalam tanaman adalah sebagai bahan pembangunan nukleoprotein yang dijumpai dalam setiap inti sel. Pembentukan sel-sel baru tanaman. Disamping fungsi utama tadi unsur $\mathrm{P}$ juga mempunyai pengaruh khas lainnya terhadap pertumbuhan tanaman. Fosfor mengaktifkan pertumbuhan tanaman, pertumbuhan bunga, mempercepat pematangan buah dan tanaman. Fosfor merangsang pertumbuhan akar, terutama akar lateral dan akar rambut.

\section{Jumlah Umbi}

Tabel 4. Hasil Pengamatan Jumlah Umbi

\begin{tabular}{|l|r|l|r|}
\hline \multicolumn{4}{|c|}{ Jumlah Umbi } \\
\hline Perlakuan & Hasil & Perlakuan & Hasil \\
\hline U1 & 3.8 & P1 & 4.8 \\
\hline U2 & 4 & P2 & 5.2 \\
\hline U3 & 4 & P3 & 5 \\
\hline U4 & 4 & P4 & 5.4 \\
\hline Jumlah & 15.8 & Jumlah & 20.4 \\
\hline
\end{tabular}




\begin{tabular}{|c|r|r|r|} 
Rata-rata & 4.0 & Rata-rata & 5.1 \\
\hline \multicolumn{2}{|c|}{ Selisih rata - rata } & 1.2 \\
\hline
\end{tabular}

Sumber: Data diolah penulis, 2020

Ket. U: tanpa mikoriza, P: dengan mikoriza, hst: hari setelah tanam.

Pemberian pupuk mikoriza menghasilkan pengaruh terhadap pembentukan umbi bawang merah, sesuai dengan fungsi mikoriza yang mampu menyerap unsur $\mathrm{p}$ lebih baik. Peranan unsur fosfat adalah untuk pembentukan umbi dan melancarkan metabolisme karbohidrat, sedangkan unsur kalium berperan untuk meningkatkan berat umbi. Hal ini diperkuat dengan selisih rerata tiap - tiap ulangan di mana lebih tinggi menggunakan mikoriza dibandingkan dengan tanpa menggunakan mikoriza. Dengan memaksimalkan peran mikoriza sebagai pengabsorbsi unsur fosfor yang baik sehingga daya serap nutrisi oleh akar tanaman jauh lebih maksimal.

\section{Keadaan Pertanian Berkelanjutan}

Perilaku petani jika dilihat secara hasil persentase terbesar masuk dalam kategori sedang (cukup paham, netral, cukup terampil), yang artinya petani tidak terlalu awam dengan konsep

Tabel 5. Perilaku Pre Test

\begin{tabular}{|c|c|c|c|c|}
\hline \multirow[b]{2}{*}{ Kategori } & \multicolumn{4}{|c|}{ Pre Pengetahuan } \\
\hline & $\mathrm{N}$ & $\%$ & SUM & $A V E R$ \\
\hline Paham & 1 & 3.1 & 33 & 33 \\
\hline Cukup Paham & 18 & 56.3 & 456 & 25 \\
\hline Kurang Paham & 13 & 40.6 & 240 & 18 \\
\hline SUM & 32 & 100 & 729 & 76 \\
\hline \multirow[t]{2}{*}{ Kategori } & \multicolumn{4}{|c|}{ Pre Sikap } \\
\hline & $\mathrm{N}$ & $\%$ & $S U M$ & $A V E R$ \\
\hline Menolak & 2 & 6.3 & 44 & 22 \\
\hline Netral & 25 & 78.1 & 412 & 16.5 \\
\hline Menerima & 5 & 15.6 & 63 & 12.6 \\
\hline SUM & 32 & 100 & 519 & 51.1 \\
\hline \multirow[t]{2}{*}{ Kategori } & \multicolumn{4}{|c|}{ Pre Keterampilan } \\
\hline & $\mathrm{N}$ & $\%$ & $S U M$ & $A V E R$ \\
\hline Terampil & 0 & 0 & 0 & 0 \\
\hline Cukup Terampil & 18 & 56.3 & 160 & 9 \\
\hline Kurang Terampil & 14 & 43.8 & 89 & 6 \\
\hline SUM & 32 & 100 & 249 & 15 \\
\hline
\end{tabular}

Sumber: Data diolah penulis, 2020
$\mathrm{N}$ : Jumlah responden, \%: Persentil responden, SUM: Jumlah skor kategori, AVER: Rerata skor kategori pertanian berkelanjutan, secara tidak langsung sebenarnya beberapa petani telah menerapkan pola tersebut. Pertanian berkelanjutan dalam aspek lingkungan atau agro production harus sudah mulai disosialisasikan dan dipraktikkan dalam petani. Dalam hasil pre test menunjukkan tingkat pengetahuan petani masih tergolong sedang ke rendah (cukup \& kurang paham) dibandingkan dengan sikap yang memperoleh hasil cukup baik yaitu dominan netral, hal ini menandakan bahwa petani masih membutuhkan informasi terkait pelaksanaan petanian secara berkelanjutan. Lain hal dengan keterampilan petani, puluhan tahun bertani telah menjadikan mereka sebagai ahli dalam bidangnya yaitu budidaya tanaman. Banyak percobaan - percobaan yang mereka buat sendiri untuk mendapatkan hasil panen yang maksimal, hasilnya keterampilan mereka akan beberapa pola penerapan pertanian berkelanjutan secara tidak langsung telah terbentuk.

Perilaku petani yang masih kultural akan tergolong memerlukan waktu dan usaha lebih agar petani menerima inovasi baru baik secara teknologi ataupun sistem yang terkonsep seperti pertanian organik, rendah kimia, terpadu dan lain - lain, pandangan pertanian hanya untuk bisnis tanpa memperhatikan faktor lainnya tidak sedikit dijumpai di lapangan. Hal ini menandakan perilaku petani harus terus diperbaiki baik dari sikap, keterampilan ataupun pengetahuannya mengenai dunia pertanian yang mereka jalani, sehingga petani dapat mandiri dan berdaya saing.

\section{Pengetahuan}

Poin pertama ditujukan untuk menggali hal yang petani ketahui tentang pertanian berkelanjutan dan pertanian yang umum dilakukan oleh petani setempat lakukan. Dan hasilnya dari keempat jawaban yang harus dijawab, petani mampu menyebutkan satu hingga tiga jawaban yang sesuai. Pada poin pertama dan kedua petani dominan menyebutkan dua perbedaan dasar yaitu pertanian berkelanjutan harus menggunakan 
input bahan organik dan mengurangi pestisida kimia sintetik.

Tabel 6. Pre Test Tingkat Pengetahuan

\section{Petani}

\begin{tabular}{|c|l|l|l|l|l|}
\hline \multicolumn{2}{|l|}{$\begin{array}{l}\text { Pengetahuan Pertanian Berkelanjutan dan } \\
\text { Pupuk Bio Mikoriza }\end{array}$} & $\mathbf{1}$ & $\mathbf{2}$ & $\mathbf{3}$ & $\mathbf{4}$ \\
\hline 1 & $\begin{array}{l}\text { Mohon Bapak/Ibu jelaskan hal yang } \\
\text { membedakan pertanian berkelanjutan dengan } \\
\text { pertanian pada umumnya? }\end{array}$ & 9 & 17 & 7 & 0 \\
\hline 2 & $\begin{array}{l}\text { Mohon Bapak/Ibu sebutkan karakteristik/ciri- } \\
\text { ciri dari pertanian berkelanjutan? }\end{array}$ & 7 & 12 & 13 & 0 \\
\hline 3 & $\begin{array}{l}\text { Mohon Bapak/Ibu sebutkan manfaat dari } \\
\text { diterapkannya pertanian berkelanjutan? }\end{array}$ & 5 & 21 & 5 & 1 \\
\hline 4 & $\begin{array}{l}\text { Mohon Bapak/Ibu sebutkan sistem pertanian } \\
\text { yang menyerupai pertanian berkelanjutan? }\end{array}$ & 9 & 17 & 6 & 0 \\
\hline 5 & $\begin{array}{l}\text { Mohon Bapak/Ibu jelaskan pengolahan lahan } \\
\text { yang sesuai dengan prinsip pertanian } \\
\text { berkelanjutan? }\end{array}$ & 7 & 18 & 7 & 0 \\
\hline 6 & $\begin{array}{l}\text { Mohon Bapak/Ibu sebutkan bahan organik } \\
\text { yang bisa digunakan untuk tanaman/media } \\
\text { tanam? }\end{array}$ & 6 & 13 & 10 & 3 \\
\hline 7 & $\begin{array}{l}\text { Mohon Bapak/Ibu sebutkan kelebihan dari } \\
\text { pupuk organik? }\end{array}$ & 4 & 10 & 16 & 2 \\
\hline $\begin{array}{l}\text { Pengetahuan Pertanian Berkelanjutan dan } \\
\text { Pupuk Bio Mikoriza }\end{array}$ & $\mathbf{1}$ & $\mathbf{2}$ & $\mathbf{3}$ & $\mathbf{4}$ \\
\hline 8 & $\begin{array}{l}\text { Mohon Bapak/Ibu sebutkan definisi dari } \\
\text { pupuk bio mikoriza? }\end{array}$ & 15 & 15 & 2 & 0 \\
\hline 9 & $\begin{array}{l}\text { Mohon Bapak/Ibu jelaskan manfaat bagi } \\
\text { pertumbuhan tanaman pada penggunaan } \\
\text { pupuk bio mikoriza? }\end{array}$ & 12 & 11 & 9 & 0 \\
\hline 10 & $\begin{array}{l}\text { Mohon Bapak/Ibu jelaskan pengaruh } \\
\text { pemberian pupuk bio mikoriza terhadap tanah? }\end{array}$ & 10 & 15 & 4 & 3 \\
\hline 11 & $\begin{array}{l}\text { Mohon Bapak/Ibu jelaskan waktu } \\
\text { pengaplikasian pupuk mikoriza pada tanaman? }\end{array}$ & 16 & 12 & 4 & 0 \\
\hline
\end{tabular}

Sumber: Data diolah penulis, 2020

Poin tiga petani harus menyebutkan beberapa manfaat pertanian berkelanjutan bagi usaha tani. Bagi petani yang telah menerapkan beberapa prinsip pertanian berkelanjutan meski secara tidak sadar, mereka mampu menjawab cukup baik dengan menyebutkan tiga manfaat, kebanyakan petani hanya mampu menjawab dua manfaat. Sedangkan pada poin empat petani diuji untuk menyebutkan beberapa sistem budidaya pertanian yang menyerupai atau sesuai dengan konsep pertanian berkelanjutan. Petani dominan menjawab dua jenis sistem yaitu pertanian organik dan pertanian rendah input kimia sintetik, jawaban ini muncul berlandaskan apa yang petani dengar bahwa pertanian organik merupakan pertanian dengan seluruh prosesnya alami mulai dari lahan, pupuk dan pestisida, sedangkan untuk pertanian rendah input kimia petani mengungkapkan bahwa untuk berkelanjutan maka harus mengurangi input kimia sintetik berlebihan. Poin lima mengharuskan petani menjelaskan beberapa metode pengolahan lahan berdasarkan prinsip pertanian berkelanjutan. berdasarkan pengalaman petani melakukan usaha tani pengolahan lahan terdapat dua metode yaitu tanpa diolah dan diolah. Tanpa diolah biasanya diterapkan pada lahan jagung dimana sebelumnya lahan tersebut ditanam padi. Jika lahan bekas tanaman padi lalu ingin dijadikan lahan bawang, maka lahan tersebut harus diolah terlebih dahulu.

Instrument poin 6 hingga 11 menitikberatkan pembahasan pada pupuk dan bahan organik. Poin 6 dan 7 menjelaskan bagaimana pengetahuan petani akan pupuk dan bahan organik untuk tanaman. Hasilnya dari empat kriteria yang diberikan, dominan petani mampu menjawab tiga bahkan ada yang mampu 4. Artinya petani memiliki kesadaran sebenarnya manfaat dari bahan organik untuk dijadikan sebagai input penting dalam usaha taninya. Poin 8 hingga 11 mengulas tentang sejauh mana pengetahuan petani tentang pupuk bio mikoriza. Di Desa Pabedilan Wetan produk ini masih tergolong inovasi karena belum sama sekali di sosialisasikan, oleh karena itu pada tabel 2 poin 8 hingga 11 menunjukkan hasil yang kurang. Petani lebih banyak menjawab 1 dan 2 poin, untuk petani yang mampu menjawab 3 atau 4 mereka bisa menganalogikan pupuk ini dengan pupuk organik lainnya sehingga mereka tahu bahwa produk ini adalah produk organik.

\section{Sikap}

\section{Tabel 7. Pre Test Respon Sikap Petani}

\begin{tabular}{|c|c|c|c|c|c|}
\hline \multicolumn{2}{|r|}{$\begin{array}{l}\text { Sikap Pertanian Berkelanjutan dan Pupuk } \\
\text { Bio Mikoriza }\end{array}$} & TS & KS & $\mathbf{S}$ & SS \\
\hline 1 & $\begin{array}{l}\text { Saya tertarik dengan penerapan pertanian } \\
\text { berkelanjutan karena berhubungan } \\
\text { dengan usaha tani yang dijalankan. } \\
\text { (Kognitif) }\end{array}$ & 1 & 16 & 15 & 0 \\
\hline 2 & $\begin{array}{l}\text { Saya mendiskusikan dengan penyuluh } \\
\text { terkait penerapan } \\
\text { berkelanjutan dalam kegiatan usaha tani. } \\
\text { (Konatif) }\end{array}$ & 1 & 17 & 13 & 1 \\
\hline 3 & $\begin{array}{l}\text { Saya merasa pemupukan dengan pupuk } \\
\text { bio mikoriza perlu diterapkan. (Afektif) }\end{array}$ & 3 & 13 & 14 & 2 \\
\hline 4 & $\begin{array}{l}\text { Saya merasa dengan penggunaan pupuk } \\
\text { bio mikoriza dapat meningkatkan hasil } \\
\text { panen. (Afektif) }\end{array}$ & 6 & 12 & 13 & 1 \\
\hline 5 & $\begin{array}{l}\text { Saya mempertimbangkan apa yang diberi } \\
\text { untuk tanaman atau media tanam. } \\
\text { (Kognitif) }\end{array}$ & 3 & 21 & 8 & 0 \\
\hline 6 & $\begin{array}{l}\text { Saya meminta rekomendasi penerapan } \\
\text { pupuk bio mikoriza. (Konatif) }\end{array}$ & 5 & 20 & 6 & 1 \\
\hline 7 & $\begin{array}{l}\text { Saya berusaha dalam menerapkan prinsip } \\
\text { pertanian berkelanjutan. (Konatif) }\end{array}$ & 2 & 17 & 13 & 0 \\
\hline
\end{tabular}

Sumber: Data diolah penulis, 2020

Dilihat dari efeknya, sikap terdiri atas tiga komponen yaitu komponen kognitif, komponen 
afektif, dan komponen konatif. Instrumen sikap poin 1 dan 5 menjelaskan bahwa petani digiring untuk membuka pendapat atau kepercayaannya tentang sesuatu yang baru yaitu konsep pertanian berkelanjutan, hasilnya pada poin 1 petani yang setuju terdapat 15 , kurang setuju 16 dan tidak setuju 1 orang. Petani yang kurang setuju menganggap bahwa ketika praktik pertanian berkelanjutan ini dilaksanakan maka akan menambah beban biaya untuk mereka. Sedangkan petani yang tidak setuju berasumsi bahwa, tindakan ini akan merepotkan petani. Terlebih para petani kecil yang tiap hari hanya bertumpu pada sektor pertanian dengan modal yang sedikit.

Poin 5 mengajak petani untuk merasakan apakah yang diberikan untuk tanaman sudah sesuai. Hasilnya jika dilihat dari tabel 7 menunjukkan petani dominan menjawab kurang setuju, ini menunjukkan bahwa apa yang diberikan petani pada tanaman merupakan sebuah keharusan yang diberikan tanpa mengetahui mengapa diberikan dan dampak apa yang diterima dari input tersebut. Tak terkecuali pemberian input kimia sintetik secara berlebihan. Poin 3 dan 4 menjelaskan bahwa petani diajak untuk menggambarkan penggunaan pupuk mikoriza pada usaha taninya. Petani yang memilih tidak/kurang setuju kurang lebih mereka belum mempercayai sepenuhnya tentang bahan organik dan pupuk mikoriza, sehingga mereka lebih memilih untuk tidak mengambil risiko lebih dalam menerapkannya. Sedangkan petani yang menjawab setuju/sangat setuju berasumsi bahwa segala macam bahan organik pasti bagus untuk tanah dan tanaman, jika memang bisa diakses petani dan terbukti bagus pasti para petani tidak ragu untuk mencobanya.

Komponen konatif terdapat pada poin 2, 6 dan 7. Poin 2 menjelaskan bahwa petani dan penyuluh saling berkoordinasi sehingga dapat menerapkan pertanian berkelanjutan, hasilnya petani masih cukup terbuka untuk menerima konsep tersebut. poin 6 menjelaskan bahwa petani memerlukan adanya rekomendasi terkait penggunaan pupuk mikoriza untuk usaha taninya, hasil dari pernyataan tersebut menunjukkan sebagian besar petani merasa kurang setuju. Karena pada dasarnya yang dibutuhkan untuk menerapkan produk pada usaha tani adalah uji coba terlebih dulu, Sehingga petani dapat mengamati dan menelaah apakah produk ini baik untuk usaha taninya atau tidak. Poin 7 berusaha untuk mengajak petani dalam menerapkan pertanian berkelanjutan dalam usaha taninya. Sama halnya dengan komponen kognitif pada poin 1, petani yang menjawab tidak/kurang setuju merasa masih awam dalam pertanian berkelanjutan, metode atau cara bertani yang mereka lakukan selama ini masih tergolong tradisional dengan input kimia sintetik lebih dominan.

\section{Keterampilan}

Keterampilan merupakan perilaku yang diperoleh melalui tahap - tahap belajar, keterampilan berasal dari gerakan - gerakan yang kasar atau tidak terkoordinasi melalui pelatihan bertahap gerakan tidak teratur itu berangsur-angsur berubah menjadi gerakangerakan yang lebih halus, melalui proses koordinasi diskriminasi (perbedaan) dan integrasi (perpaduan) sehingga diperoleh suatu keterampilan yang diperlukan untuk tujuan tertentu.

Tabel 8. Pre Test Tingkat Keterampilan

\section{Petani}

\begin{tabular}{|l|l|l|l|l|l|}
\hline $\begin{array}{l}\text { Keterampilan Pertanian Berkelanjutan } \\
\text { dan Pupuk Bio Mikoriza }\end{array}$ & $\mathbf{1}$ & $\mathbf{2}$ & $\mathbf{3}$ & $\mathbf{4}$ \\
\hline 24 & $\begin{array}{l}\text { Mohon lakukan pengolahan lahan } \\
\text { dengan penerapan pertanian } \\
\text { berkelanjutan }\end{array}$ & 6 & 17 & 8 & 1 \\
\hline 25 & $\begin{array}{l}\text { Mohon lakukan pemupukan dengan } \\
\text { penerapan pertanian berkelanjutan }\end{array}$ & 10 & 16 & 5 & 1 \\
\hline 26 & $\begin{array}{l}\text { Mohon lakukan pemupukan bio } \\
\text { mikoriza sesuai anjuran }\end{array}$ & 9 & 20 & 3 & 0 \\
\hline 27 & $\begin{array}{l}\text { Mohon Lakukan pengendalian hama } \\
\text { dengan prinsip PHT }\end{array}$ & 10 & 15 & 8 & 1 \\
\hline
\end{tabular}

Sumber: Data diolah penulis, 2020

Keempat poin ini diambil berdasarkan pokok inti dari pertanian berkelanjutan yaitu pengolahan lahan, pemupukan, bahan organik dan pengendalian hama penyakit. Pada poin 1 petani menjelaskan pengolahan lahan yang dilakukan oleh petani, hasilnya terdapat 6 orang mampu menerapkan satu prinsip pengolahan lahan berkelanjutan, 17 orang mampu 
menerapkan dua prinsip, 8 orang mampu menerapkan 3 prinsip dan 1 orang mampu menerapkan 4 prinsip. Dalam pengolahan pertanian secara berkelanjutan petani sebenarnya sadar bahwa penambahan input organik, pengolahan minimum jika akan ditanam bawang kembali atau tanpa olah tanah jika ditanam jagung, minimalisir penggunaan mesin pertanian juga diterapkan petani karena kondisi sosial petani masih terpaku pada kultur masyarakat yang mayoritas buruh tani sebagai pekerjaan utama.

Pada poin 2 menjelaskan tentang pemupukan yang dilakukan oleh petani dan kesesuaian dengan penerapan pertanian berkelanjutan. Hasil menunjukkan 10 orang menerapkan satu prinsip, 16 orang menerapkan 2 prinsip, 5 orang menerapkan 3 prinsip dan 1 orang menerapkan 4 prinsip. Kebiasaan petani ketika pemupukan masih melebihi dosis. Petani beranggapan bahwa semakin banyak pupuk kimia sintetik maka dampak yang dihasilkan untuk tanaman lebih efektif dalam meninkatkan produksi. Akan tetapi petani masih sadar bahwa bahan - bahan organik diperlukan untuk tanaman, hal ini berkaitan dengan dampak yang telah dirasakan oleh petani yaitu degradasi lahan.

Poin ke 3 petani harus mencoba menerapkan pemupukan mikoriza sebelum diberi anjuran. Hasilnya sebanyak 9 orang petani hanya mampu menerapkan 1 prinsip, 20 petani mampu menerapkan 2 prinsip, 3 petani mampu menerapkan 3 prinsip dan untuk 4 prinsip petani belum sampai. Ini menandakan bahwa petani masih sangat baru tentang produk pupuk bio mikoriza. Poin ke 4 adalah pengendalian hama dan penyakit dengan prinsip pengendalian hama dan penyakit secara terpadu. Hasil keterampilan petani yaitu sebanyak 10 orang mampu menerapkan 1 prinsip, 15 orang mampu menerapkan 2 prinsip, 8 orang mampu menerapkan 3 prinsip dan 1 orang mampu menerapkan 4 prinsip. Penggunaan pestisida kimia sintetik masih dominan dilakukan oleh petani karena dampak yang dihasilkan cukup berimbang dengan hasil yang didapatkan. Akan tetapi tidak sedikit juga petani yang telah berhasil mengkombinasikan teknologi yellow trap dan produk bio pestisida sehingga meminimalisir penggunaan dan biaya dari pestisida kimia sintetik.

\section{Perubahan Perilaku Melalui Penyuluhan Pertanian \\ Penyuluhan Pertanian}

Menurut UU no 16 tahun 2006 tentang sistem penyuluhan pertanian, perikanan dan kehutanan menjelaskan bahwa, penyuluhan pertanian adalah proses pembelajaran bagi pelaku utama serta pelaku usaha agar mereka mau dan mampu menolong dan mengorganisasikan dirinya dalam mengakses informasi pasar, teknologi, permodalan, dan sumber daya lainnya, sebagai upaya untuk meningkatkan produktivitas, efisiensi usaha, pendapatan, dan kesejahteraannya, serta meningkatkan kesadaran dalam pelestarian fungsi lingkungan hidup.

\section{Materi}

Materi yang digunakan memuat dua poin utama bahasan yaitu tentang pertanian berkelanjutan dan pupuk bio mikoriza. Materi ini termasuk dalam pengembangan sumber daya manusia, ilmu pengetahuan, teknologi, dan pelestarian lingkungan. Materi penyuluhan menurut UU no 16 tahun 2006 tentang sistem penyuluhan pertanian, perikanan dan kehutanan menjelaskan bahwa meteri penyuluhan harus memuat unsur pengembangan sumber daya manusia dan peningkatan modal sosial serta unsur ilmu pengetahuan, teknologi, informasi, ekonomi, manajemen, hukum, dan pelestarian lingkungan. Materi ini tertuang pada lembar kerja menyuluh dan sinopsis sehingga mempermudah dalam pengaturan jadwal kegiatan penyuluhan.

\section{Media}

Efektifitas penggunaan media baik langsung atau tidak langsung tergantung dari responden, seperti halnya penelitian ini menggunakan media langsung dan tidak langsung karena menyesuaikan dengan kondisi pada petani yang tidak semuanya sama. Media langsung seperti wawancara dan pemutaran video digunakan untuk menggali informasi dari petani dan juga untuk berdiskusi sehingga 
tercapai tingkatan pemahaman yang sama, sedangkan media tidak langsung seperti leaflet digunakan untuk meningkatkan kemungkinan petani untuk terus mengingat hal - hal yang telah di diskusikan.

\section{Metode}

Metode membahas cara yang digunakan agar materi yang telah disusun dan media yang ada dapat meningkatkan penyerapan informasi oleh para petani. Metode terbagi menjadi 3 jenis yaitu, berdasarkan pendekatan perorangan, berdasarkan pendekatan kelompok dan berdasarkan pendekatan masal. Metode penyuluhan yang digunakan pada penelitian ini adalah a) Anjangsana/kunjungan rumah di mana mendatangi para petani secara satu persatu; b) Pameran yaitu uji coba teknologi yang dilakukan oleh peneliti ditunjukkan kepada petani berupa gambar/video; c) Pemutaran film/video berupa pemutaran mengenai materi yang disampaikan yaitu pertanian berkelanjutan dan pupuk bio mikoriza; d) Penyebaran leaflet berupa pemberian leaflet yang berisi materi tentang pertanian berkelanjutan dan pupuk bio mikoriza; e) Diskusi yaitu suatu pertemuan yang jumlah pesertanya tidak lebih dari 20 orang biasanya diadakan untuk bertukar pendapat mengenai suatu kegiatan yang akan diselenggarakan, atau mengumpulkan saran saran untuk memecahkan permasalahan.

\section{Kegiatan Penyuluhan}

Penyuluhan menggunakan metode anjangsana/kunjungan rumah yang mana merupakan salah satu anjuran untuk melakukan kegiatan ditengah pandemi virus covid-19, dengan mempertimbangkan berbagai aspek kesehatan seperti halnya jaga jarak, penggunaan masker dan cuci tangan, pelaksanaan kegiatan penyuluhan dapat terlaksana dengan baik. dimulai dengan mengunjungi para ketua kelompok untuk melakukan diskusi, di mana sebelumnya melakukan perjanjian untuk bertemu. Kepada ketua kelompok dilakukan perizinan untuk mewawancarai para pengurus dan anggotanya, setelah itu baru dilakukan wawancara dengan pengurus dan anggota.

Hasil dari wawancara kepada petani ini adalah data pre dan post test sehingga dapat diolah menjadi sebuah informasi mengenai perilaku petani. kegiatan wawancara dimulai dengan pengenalan dan maksud tujuan, setelah itu pengisian kuesioner pre test pengetahuan dan sikap lalu dilakukannya diskusi dengan penambahan media pemutaran video dan terakhir adalah pemberian leaflet sebagai media cetak penyuluhan, post test dilakukan pada beberapa hari selanjutnya. Dalam pengisian kuesioner keterampilan, peneliti melihat langsung bagaimana para petani di lapangan sehingga kuesioner bersifat terbuka yang artinya petani bebas untuk mendapatkan nilai sesuai dengan kriteria peneliti.

\section{Perubahan Perilaku Petani}

Hasil pre test pengetahuan dan keterampilan petani masih didominasi masuk dalam kategori rendah sementara untuk sikap dominan pada kategori sedang. Hal ini berkaitan dengan metode penyuluhan yang sesuai untuk meningkatkan perilaku petani sehingga petani mau dan mampu menerapkan pertanian berkelanjutan meski beberapa poin akan tetapi itu merupakan sebuah loncatan bagi petani untuk menjadi lebih baik. Hasil dari perubahan perilaku ini tercermin pada tabel 9 , dengan metode sederhana yaitu membandingkan hasil dari pre dan post test berdasarkan beberapa kategori untuk masing masing komponen perilaku (pengetahuan, sikap dan keterampilan).

Menurut terori Bloom yang dikutip dalam Notoatmodjo (2007) mengemukakan bahwa, membedakan sebuah perilaku dalam tiga perilaku yaitu kognitif (Cognitive) adalah merupakan hasil dari tahu, dan ini 
Tabel 9. Perubahan Perilaku

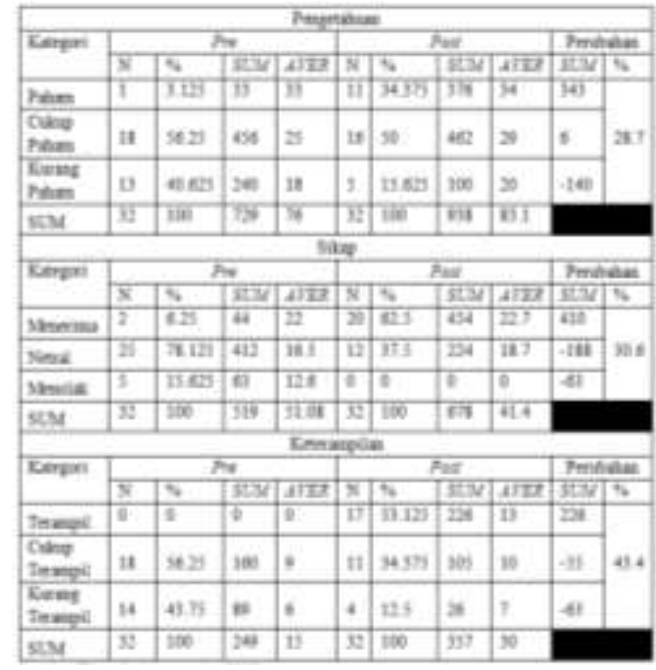

Sumber: Data diolah penulis, 2020

$\mathrm{N}$ : Jumlah responden, \%: Persentil responden, $S U M$ : Jumlah skor kategori, AVER: Rerata skor kategori

terjadi setelah orang melakukan pengindraan terhadap suatu obyek tertentu, afektif (Affective) adalah sikap secara nyata menunjukkan konotasi adanya kesesuaian reaksi terhadap stimulus tertentu yang dalam kehidupan sehari-hari merupakan reaksi yang bersifat emosional terhadap stimulus sosial. dan psikomotor (Psychomotor) adalah kemampuan seseorang untuk bertindak setelah menerima pengalaman belajar tertentu.

\section{Aspek pengetahuan}

Petani mengalami banyak peningkatan menjadi kriteria paham. Hal ini terlihat mulai dari jumlah responden yang meningkat pada kategori tersebut, jumlah skor kategori paham juga meningkat kurang lebih sebanyak 343. Sedangkan pada kategori rendah terjadinya penurunan yang cukup signifikan pula yaitu sebesar 140 skor ditandakan juga dengan berkurangnya responden pada kategori tersebut. Peningkatan dalam

aspek pengetahuan ini menandakan petani secara keilmuan sudah bisa menerapkan pertanian berkelanjutan dan pemupukan bio mikoriza dengan bimbingan penyuluh atau pihak lainnya yang dianggap lebih ahli menangani hal tersebut. Para petani yang sebelumnya ragu dalam penerapannya menjadi cukup yakin bahwa beberapa komponen pada konsep ini telah dilakukan petani sehingga petani hanya perlu beradaptasi lebih untuk menerapkan.

Petani yang masuk dalam kategori kurang paham berjumlah 5 orang dengan jumlah skor rerata yang terjawab 20, mereka masih kurang setuju dengan penerapan ini tetap beranggapan bahwa konsep ini hanya cocok untuk petani yang memiliki lahan atau sawah pribadi sehingga apa yang mereka masukkan untuk tanah pasti berguna untuk lahannya dikemudian hari, kalau petani dengan lahan sewa untuk menerapkan konsep tersebut membutuhkan biaya lebih sedangkan kontinuitas dari lahan sewa tergantung pemilik lahan.

Penerapan mikoriza dianggap memiliki fungsi seperti halnya pupuk organik lainnya yaitu penyuburan tanah, tetapi setelah dilakukannya penyuluhan, para petani mengetahui bahwa mikoriza dapat menjadi solusi dari kekeringan. Ketika lahan memasuki musim kemarau seperti sekarang yang terjadi pada bulan Mei, Juni, Juli. Para petani yang biasa menggunakan bibit/umbi bawang dari pasar diberikan sebuah alternatif agar bibit/umbi cepat tumbuh dengan memanfaatkan mikoriza melalui salah satu fungsinya yaitu pengoptimalan penyerapan unsur fosfor dalam tanah dengan memperluas area penyerapan akar lebih optimal.

\section{Sikap}

Hasil post test yang menunjukkan hasil sangat baik, tidak ada petani yang masuk dalam kategori menolak bahkan kategori menerima meningkat. Dari jumlah petani sebanyak 18 petani masuk dalam kategori menerima dengan jumlah skor yang bertambah sebesar 410 atau sebanyak $45.8 \%$ sedangkan pada kategori menolak tidak terdapat petani. Dengan hasil ini menjadikan bahwa penyuluhan yang dilakukan dapat dikatakan dapat merubah pandangan dan persepsi petani tentang pertanian berkelanjutan. Menurut Zuchdi (1995) mengatakan bahwa, Perubahan sikap terjadi apabila informasi yang bersifat persuasif dipahami dan diterima oleh penerima, informasi ini kemudian mengendap dan disetujui oleh penerima informasi. 
Secara konatif petani sudah lebih baik dibandingkan dengan awal pre test, yang awalnya masih ragu dapat berubah menjadi yakin bahwa pertanian berkelanjutan harus sudah dilaksanakan meski baru penerapan pupuk organik pada lahannya. Lalu secara afektif petani rasa konsep ini masih terlalu luas/kompleks sehingga petani bingung apa yang harus dilakukan akan tetapi jika dilihat dari output hasil pertanian berkelanjutan petani merasa bahwa hal ini memang diperlukan bagi pertanian masa akan datang.

\section{Keterampilan}

Petani diupayakan untuk meningkatkan keterampilan yang bersinergi dengan peningkatan pengetahuan petani tentang pertanian berkelanjutan. Hasilnya adalah terjadi peningkatan keterampilan petani sebanyak 17 petani masuk dalam kategori terampil dengan jumlah skor yang terjawab sebanyak 226 atau mengalami peningkatan sebesar $44 \%$ sedangkan pada kategori kurang terampil mengalami penurunan dengan jumlah 10 orang pada kategori rendah di mana sebelumnya terdapat 14 orang, pada kategori cukup terampil sebelumnya 18 orang menjadi 11 orang petani. Peningkatan keterampilan ini menandakan petani mampu untuk menerapkan pertanian berkelanjutan diimbangi dengan pengetahuan yang bertambah.

Ketika petani telah tergolong dalam kategori terampil, langkah kedepan adalah mendorong petani untuk mau melaksanakan pertanian berkelanjutan secara kontinu dalam usaha tani yang mereka jalankan. Pada dasarnya petani mampu dan mau untuk melakukan sesuatu yang lebih baik terlebih untuk usaha taninya, dengan bimbingan intensif dan metode yang sesuai menjadikan perilaku petani semakin lebih baik dan daya saing petani meningkat, bukan pada kasta selalu menunggu dan ketergantungan.

\section{Strategi Penerapan Pertanian Berkelanjutan dan Pupuk Bio Mikoriza}

Banyak hal yang mempengaruhi petani untuk merubah perilakunya, literasi - literasi terkait penyuluhan ataupun pertanian secara sosial ekonomi banyak menjelaskan bahwa secara garis besar terbagi atas internal dan eksternal petani itu sendiri. Internal mencakup: umur, pendidikan, kondisi keluarga, tanggungan petani, lingkungan, faktor ini kerap dijadikan sebagai penelitian dengan obyek gambaran kondisi petani, sedangkan faktor eksternal petani merupakan hal - hal yang di luar dan tidak menyangkut petani secara langsung contohnya, kondisi lahan, musim, pasar, kelompok tani, penyuluh dan sebagainya. Dengan dilakukannya wawancara secara langsung menjadikan informasi yang didapat cukup kompleks sehingga mampu diambil beberapa hal terkait dengan kekuatan, kelemahan, peluang dan ancaman usaha tani bawang merah di Desa Pabedilan Wetan Kabupaten Cirebon.

\section{Tabel 10. Strategi Penerapan Pertanian} Berkelanjutan \& Pemupukan Bio Mikoriza

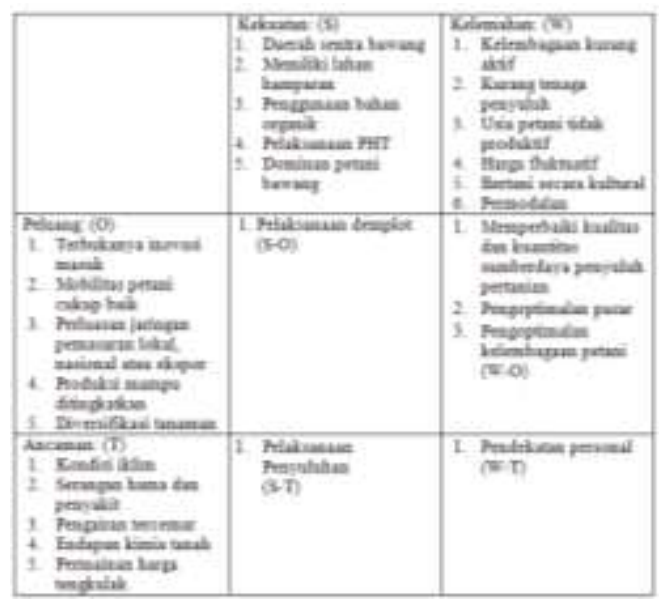

Sumber: Data diolah penulis, 2020

1. Memperbaiki kualitas dan kuantitas sumber daya penyuluh pertanian, hal ini dilandaskan bahwa penyuluh merupakan faktor penentu terjadinya perubahan perilaku pada petani. Menurut Mardikanto (2009) mengemukakan bahwa, kegiatan penyuluhan sangat diperlukan untuk memperlancar pembangunan pertanian. Perubahan perilaku petani berkaitan erat dengan kehadiran penyuluh dalam melakukan pendampingan, keterbatasan pendidikan petani menjadi kendala tersendiri, oleh karenanya kehadiran 
penyuluh pertanian dirasakan sangat membantu petani melakukan kegiatannya.

2. Pelaksanaan demplot, demplot pada dasarnya dilakukan oleh petani sehingga petani mampu belajar dari kegiatan lapangan tersebut, tentu dengan bimbingan dari penyuluh ataupun stakeholder pertanian. Metode demplot merupakan salah satu metode yang cukup baik jika diterapkan sebagai penyampaian informasi berupa produk atau pun konsep teknis lainnya. Menurut Hindersah (2016), metode demplot oleh petani dianggap dapat meningkatkan hasil karena selama ini tidak ada pembanding. Berdasarkan demplot, data produktivitas menjadi lebih pasti karena bobot per ikat setiap jenis sayuran daun dapat ditetapkan. Dengan demikian petani akan mau dan mampu untuk mencoba hal tersebut, sehingga terjadilah perubahan perilaku menjadi lebih baik.

3. Pendekatan personal, merupakan sebuah modal kasatmata akan tetapi memiliki pengaruh yang cukup besar dalam pengambilan keputusan seorang petani. Sebagaian besar petani saat ini masih tergolong sebagai petani kecil karena menggantungkan hidupnya pada dunia pertanian akan tetapi tidak memiliki rencana terhadap usaha taninya. menurut Leeuwis (2006), orang lain cenderung untuk memilih kontak antar personal dengan seseorang yang mereka percaya memiliki kompeten dan bermotivasi. Para tengkulak memiliki metode tersendiri dalam melakukan pendekatan terhadap para petani sehingga petani mau menjual hasil panennya pada tengkulak tersebut. Hal ini merupakan salah satu kondisi bahwa pendekatan secara personal kepada para petani akan berpengaruh terhadap keputusan yang diambil oleh petani termasuk perilakunya.

4. Pengoptimalan pasar, pasar yang dijangkau oleh hampir seluruh petani adalah para tengkulak, hanya saja terdapat beberapa petani yang mampu memasarkan langsung pada pasar tradisional. Dengan segmentasi pasar yang hanya mampu menjangkau para tengkulak menjadikan harga pada tingkat petani lebih rendah dibandingkan pada tingkat pasar. Hal ini akan mempengaruhi keputusan petani dalam menerapkan hal baru pada usaha taninya, ketika kondisi pasar yang fluktuatif para petani akan merespon dengan produksi optimal menggunakan bahan kimia sintetik sehingga hasil langsung bisa didapatkan, berbeda dengan bahan organik yang memerlukan proses lebih lama dan kontinu bila diaplikasikan pada tanaman.

5. Pengoptimalan kelembagaan petani, sesuai dengan apa yang ditulis pada peraturan menteri pertanian nomor 67 tahun 2016 tentang pembinaan kelembagaan penyuluhan, menjelaskan bahwa pembinaan kelompok dilaksanakan secara berkesinambungan dan diarahkan pada upaya peningkatan kemampuan Poktan dalam melaksanakan fungsinya sebagai (1) kelas belajar; (2) wahana kerjasama; dan (3) unit produksi, sehingga mampu mengembangkan Usahatani dan menjadi Kelembagaan Petani yang kuat dan mandiri.

6. Penyuluhan Pertanian, pelaksanaan penyuluhan didasarkan pada tiga aspek penting yaitu perumusan materi, penyusunan media dan perencanaan metode penyuluhan. Kegiatan penyuluhan berlandaskan pada UU No 16 tahun 2006 tentang Sistem Penyuluhan Pertanian, Perikanan, Dan Kehutanan, sedangkan pedoman dalam pelaksanaannya diperbaharuhi pada tahun 2018 dengan munculnya permentan No 3 tahun 2018 tentang Pedoman Penyelenggaraan Penyuluhan Pertanian. Keterkaitan penyuluhan pertanian dengan petani tidak bisa direlakan, pasalnya dengan penyuluhan para petani diupayakan untuk berubah baik secara pengetahuan, sikap ataupun keterampilan. Hal ini perlu ditekankan bahwa kegiatan penyuluhan harus lebih dioptimalkan sehingga petani 
terayomi dan mampu mengatasi permasalahan usaha taninya dengan mandiri.

\section{PENUTUP}

\section{Kesimpulan}

1. Tekonologi pupuk bio mikoriza pada tanaman bawang mendapatkan hasil yang baik, dengan signifikannya nilai pengaruh pemberian mikoriza terhadap variabel independent dengan taraf error 0.05 menunjukkan pemberian mikoriza memiliki perbedaan secara nyata dibandingkan dengan tidak menggunakan, dan mean yang menunjukkan selisih lebih besar diberikan pada perlakuan pemberian mikoriza.

2. Kondisi perilaku petani sebelum dilakukannya penyuluhan tentang pertanian berkelanjutan dan pemupukan bio mikoriza tergolong dalam kategori sedang ke rendah. aspek pengetahuan ditandai dengan jumlah responden pada kategori kurang paham berjumlah 40,6\% atau 13 orang dan cukup paham berjumlah $56,3 \%$ atau 18 orang. Aspek sikap didominasi kategori netral dengan jumlah $78,1 \%$ atau 25 orang dan pada aspek keterampilan seperti halnya pengetahuan responden hanya mampu menempati kategori cukup terampil berjumlah 56,3\% atau 18 orang dan kurang terampil berjumlah $43,8 \%$ atau 14 orang.

3. Penyuluhan dengan metode anjangsana serta media dan metode yang di sinergikan agar petani mampu memahami lebih baik, menjadikan terjadinya peningkatan perilaku petani. Jika dilihat pada peningkatan jumlah skor aspek pengetahuan terjadi peningkatan sebesar $28,7 \%$, sikap sebesar 30,6\% dan keterampilan sebesar 43,4\%. Dengan dilakukannya analisa SWOT dirumuskan beberapa strategi dalam penerapan pertanian berkelanjutan dan pupuk bio mikoriza antara lain memperbaiki kualitas dan kuantitas sumber daya penyuluh pertanian, pelaksanaan penyuluhan, pelaksanaan demplot dengan petani sebagai perencana dan pelaksana, pendekatan personal pada petani, mengoptimalkan pasar bagi petani, pengoptimalan kelembagaan petani.

\section{Saran}

1. Kondisi pertanian berkelanjutan:

a) Perlunya sinergitas antar lini bidang pertanian agar konsep pertanian berkelanjutan dapat dilaksanakan, urgensi pertanian berkelanjutan seharusnya terdapat kebijakan agar mampu bergerak menuju hal tersebut.

b) Monitoring dan evaluasi lebih agar mampu memetakan apa yang dipermasalahkan dan diharapkan oleh petani.

2. Perubahan perilaku petani:

a) Pemerataan akses informasi pada petani melalui strategi penyuluhan yang telah tertuang pada data Balai Penyuluhan Pertanian setempat.

b) Dilakukannya bimbingan baik pada kelompok tani ataupun petani secara langsung tentang pemasaran bawang merah dan budidaya untuk meningkatkan hasil produksi dengan berbasis lingkungan.

3. Uji teknologi pupuk bio mikoriza:

a) Perlunya demplot untuk petani dengan petani sebagai perencana, pelaksana dan evaluator melalui bimbingan berskala oleh penyuluh atau stakeholder pertanian.

\section{DAFTAR PUSTAKA}

[1] Aprianti, S. D., dan Suryanto. A. 2018. Efektivitas Penggunaan Mikoriza dan PGPR (Plan Growth Promoting Rhizobacteria) Terhadap Tanaman Bawang Merah (Allium azcalonium L) Pada Pipa PVC Sistem Veltikultur. Jurnal Produksi Tanaman Vol 6 No 4 : 635 - 641. ISSN: $2527-8452$. 
[2] BPP Pabedilan. 2019. Programa Kecamatan. Kabupaten Cirebon: BPP Pabedilan.

[3] BPP Pabedilan. 2019. RKTP Pabedilan Wetan. Kabupaten Cirebon: BPP Pabedilan.

[4] Leeuwis, C. 2006. Komunikasi Untuk Inovasi Pedesaan. Yogyakarta: Kanisius.

[5] Malherbe, T. de. 1964. Soil fertility. Fith ed. London. New York London. New York: Oxford University Press.

[6] Mardikanto, T. 2009. Sistem Penyuluhan Pertanian. Surakarta: Sebelas Maret University.

[7] Notoatmodjo, S. 2007. Promosi Kesehatan dan Ilmu Perilaku. Jakarta: Rineka Cipta.

[8] Permentan Republik Indonesia No.67/Permentan/SM.050/12/2016

Tentang Pembinaan Kelembagaan Petani. Jakarta. Kementerian Pertanian.

[9] Prihastuti. 2007. Isolasi dan karakterisasi mikoriza vesikular-arbuskula di lahan kering masam. Lampung Tengah. Berk. Penel. Hayati: 12 (99-106).

[10]R. Hindersah. dkk. 2016. Penggunaan Demonstrasi Plot Untuk Mengubah Metode Aplikasi Pupuk Organik Pada Lahan Pertanian Sayuran Di Kota Ambon. Jurnal Aplikasi Ipteks untuk Masyarakat, Vol. 5, No. 1, Mei 2016: 9 - 15, 1410 5675.

[11]Rivai, Rudy S. \& Anugrah, Iwan S. 2011. Konsep Dan Implementasi Pembangunan Pertanian Berkelanjutan Di Indonesia. Forum Penelitian Agro Ekonomi, Volume 29 No. 1, Juli 2011: 13 - 25. Pusat Sosial Ekonomi Dan Kebijakan Pertanian Jl. A. Yani No. 70 Bogor 16161.

[12]Rukmana, R. 1994. Bawang Merah, Budidaya dan Pengolahan Pasca Panen. Yogyakarta: Kanisius.

[13] Schmidt, F. H., dan Ferguson, J. H. A. 1951. Rainfall Types Based On Wet and Dry Period Rations for Indonesia With Western New Guinea. Jakarta: Kementrian Perhubungan Meteorologi dan Geofisika.
[14] Sugiyono. 2016. Metode Penelitian Kuantitatif, Kualitatif dan R\&D. Bandung: PT Alfabet.

[15] Suryani, R. dkk. 2017. Respon Tanaman Bawang Merah Terhadap Cendawan Mikoriza Arbuskula (CMA) Pada Cekaman Kekeringan Di Tanah Gambut. Jurnal Pedon Tropika Edisi 1 Vol 3 (6978).

[16] Tinker P. B. H. 1975. Effects of vesiculararbuscular mycorrhizas on higherplants. Symp. Soc. Expt. Biol. 29: 325-349.

[17]Undang - undang No. 16 Tahun 2006 Tentang Pelaksanaan Penyuluhan Pertanian, Perikanan dan Kehutanan. Jakarta: Pemerintah Indonesia.

[18] Wikipedia. 2020. Pertanian. https://id.wikipedia.org/wiki/Pertanian.

Diakses pada tanggal 2 Februari 2019 pukul 09.12.20 WIB.

[19]Zuchdi, D. 1995. Pembentukan Sikap. Cakrawala Pendidikan No. 3 tahun XIV. 
HALAMAN INI SENGAJA DIKOSONGKAN 